\title{
DIGITAL SKILLS AND PROFILE OF EACH GENERATION: A REVIEW
}

\author{
Elisa Cirilli \\ University of Macerata (ITALY) \\ elisa7293@gmail.com \\ Paola Nicolini \\ University of Macerata (ITALY)
}

Fecha de Recepción: 9 Febrero 2019

Fecha de Admisión: 30 Abril 2019

\section{ABSTRACT}

The technological development is changing, involving and conditioning everyday life, making it faster, hyper-connected and immediate. New technologies can have a double outcome: positive, given that they take on the role of facilitator, or negative, when people tend to make excessive and unconscious use of it or technology repeatedly replaces human beings. Today, therefore, new skills are needed for the entire population, the digital skills, both in everyday life and in the labour market.

These are transversal skills that allow human beings to choose the right technologies: to research, analyze data and choose reliable information from those that require further study, to check and verify the health of people, to interact with different and distant subjects in the world, to improve school learning, ... The plurality of people that this technological development is involving allows us to analyze the population in terms of generations, from Silent Generation to Alpha Generation. In this article we want to present a literature review within the Google Scholar database in the last 10 years using the terms digital skills and different generation.

This preliminary research allows us to analyze the different theories that make for the Digital Skills a definition, dimensions and evaluation model, and the generational profiles in order to have a shared and common theory among the different professionals.

Having an accurate background of digital skills and generational profiles favours the inclusion of all people, and the improvement of the quality of life in the creation of psycho-pedagogical projects and in the design of technological products.

Keywords: digital skills; cohorts; different generation; digital literacy; technological interaction

\section{OBJECTIVES OF THE INVESTIGATION}

Nowadays, technological development is changing, involving and conditioning everyday life, making it faster, hyper-connected and immediate. The introduction of new technologies in everyday life can be positive, if they take on the role of facilitator, or negative, if people tend to make excessive and unconscious use of it or the technology repeatedly replaces human beings. The entire pop- 


\section{DIGITAL SKILLS AND PROFILE OF EACH GENERATION: A REVIEW}

ulation needs new skills, digital skills, which allow people to make positive and conscious use of various technologies. They are transversal skills that allow the human being to choose the appropriate technologies: to search, analyze data and choose reliable information from those that require further study, to check and verify the health of people, to interact with different and distant subjects in the world, to improve school learning, ... The fields of action in which technologies can be applied touches different contexts and a vast plurality of people. This allows us to analyze the population in terms of generations, from Silent Generation to Alpha Generation. Therefore, the aim was to study and analyze the most complete theories about digital skills and the generational profiles of the entire population. These objectives were chosen in order to have a theoretical and shared overview in order to carry out a profound analysis on the interaction between each generation and the different technologies. It is also believed that the multidisciplinary nature of this topic requires a theoretical approach shared by all the various professionals working in the sector.

\section{SAMPLE AND / OR PARTICIPANTS}

The research was carried out through a literature review in the Google Scholar database between January and March 2019. We have analyzed the papers published from 2009 to 2019 in the language of Italian and English.

\section{METHODOLOGY AND / OR INSTRUMENTS USED}

A search of national and international literature was conducted on the topic "generations and technologies" that arises from a question: How do the various generations perceive human-technology interaction? This question was solved in two sub-questions: do the characteristics of each generation affect the respective perception? Does the digital skills possessed by each generation modify perception?

These questions were attempted to respond with two researches: a preliminary one, which would allow us to focus more precisely on the field of research and bring out the underlying theories, and a more complete and focused one, which would bring out the interaction between generation and technology. Both researches were carried out through a literature review in the Google Scholar database between January and March 2019. In this paper we will illustrate the results regarding the preliminary research that was done by choosing two keywords: "digital skills" and "different generations". In addition, criteria for inclusion and exclusion of publications have been developed: the research was carried out by including the articles with the two keywords: "digital skills", the definition, the dimensions and the competence assessment model; "different generations", the minimum of 4 generation's classification and comparison, the presence of common indicators for each generation. On the contrary, publications different from Italian and English have been excluded, contents published before 2009 and articles not available free of charge.

\section{RESULTS}

The selection made on the basis of the criteria and the analysis of the contents of the data present in the publications, has led to the inclusion of $n^{\circ} 6$ articles that have been divided according to the keywords in this way: $\mathrm{n}^{\circ} 2$ publications for "digital skills" (Table 1), $\mathrm{n}^{\circ} 4$ for the "different generation" (Table 2). 
Table 1. Literature Review for "digital skills"

\begin{tabular}{l|l|l}
\hline \hline Authors & Title & $\begin{array}{l}\text { Year of } \\
\text { publication }\end{array}$ \\
\hline $\begin{array}{l}\text { A. Calvani, A. Fini, \& } \\
\text { M. Ranieri }\end{array}$ & $\begin{array}{l}\text { Valutare la competenza digitale. Modelli teorici e } \\
\text { strumenti applicativi. }\end{array}$ & 2009 \\
\hline $\begin{array}{l}\text { S. Carretero, R. R. } \\
\text { Vuorikari \& Y. Punie }\end{array}$ & $\begin{array}{l}\text { DigComp 2.1: The Digital Competence Framework for } \\
\text { Citizens with eight proficiency levels and examples of } \\
\text { use. }\end{array}$ & 2017 \\
\hline \hline
\end{tabular}

Table 2. Literature Review for "different generations"

\begin{tabular}{l|l|l}
\hline Authors & \multicolumn{1}{|c|}{ Title } & $\begin{array}{l}\text { Year of } \\
\text { publication }\end{array}$ \\
\hline S. B. Berkup & $\begin{array}{l}\text { Working with generations X and Y in generation Z } \\
\text { period: Management of different generations in } \\
\text { business life }\end{array}$ & 2014 \\
\hline $\begin{array}{l}\text { T. Hernaus \& N. } \\
\text { Pološki Vokic }\end{array}$ & $\begin{array}{l}\text { Work design for different generational cohorts: } \\
\text { Determining common and idiosyncratic job } \\
\text { characteristics. }\end{array}$ & 2014 \\
\hline D. Velički, V. Velički & $\begin{array}{l}\text { Characteristics and particularities of educating the net- } \\
\text { generation }\end{array}$ & 2015 \\
\hline $\begin{array}{l}\text { T. Botteri, G. } \\
\text { Cremonesi }\end{array}$ & $\begin{array}{l}\text { Millennials e oltre! Nuove generazioni e paradigmi } \\
\text { manageriali. }\end{array}$ & 2019 \\
\hline \hline
\end{tabular}

Regarding the analysis of the publications in table 1, there are two research groups that have been analyzed Calvani, Fini, Ranieri (2009) and those of Carretero, Vuorikari, Punie (2017). For both publications the definition, the dimensions and the competence assessment model were analyzed (Table 3).

Table 3. Digital Skills: definitions, dimensions and competence assessment models

\begin{tabular}{|c|c|c|c|}
\hline Authors & Definitions & Dimensions & $\begin{array}{l}\text { Competence } \\
\text { assessment models }\end{array}$ \\
\hline $\begin{array}{l}\text { A. Calvani, A. Fini, } \\
\text { \& M. Ranieri }\end{array}$ & $\begin{array}{l}\text { Digital competence is a } \\
\text { framework of } \\
\text { articulated } \\
\text { competences that } \\
\text { include not only the } \\
\text { possession } \\
\text { procedural skills, but } \\
\text { also more complex } \\
\text { components, such as } \\
\text { the ability to analyze } \\
\text { and evaluate data, } \\
\text { represent and solve } \\
\text { problems, explore } \\
\text { unknown technological } \\
\text { contexts, establish } \\
\text { collaborative synergies } \\
\text { between multiple } \\
\text { subjects. }\end{array}$ & $\begin{array}{l}\text { Three dimensions: } \\
\text {-Technological } \\
\text { dimension: basic skills } \\
\text { and notions that allow } \\
\text { exploring, evaluating, } \\
\text { exchanging } \\
\text { information and } \\
\text { knowing how to choose } \\
\text { appropriate } \\
\text { technologies in a } \\
\text { flexible way; } \\
\text { - Cognitive dimension: } \\
\text { being able to read, } \\
\text { select, interpret and } \\
\text { critically evaluate data, } \\
\text { abstract models and } \\
\text { information their } \\
\text { considering }\end{array}$ & $\begin{array}{l}\text { Two different types of } \\
\text { tools: } \\
\text { - Instant DCA: } \\
\text { quantitative testing; } \\
\text { - Situated DCA: tests } \\
\text { located in real contexts. }\end{array}$ \\
\hline
\end{tabular}




\begin{tabular}{|c|c|c|c|}
\hline & & $\begin{array}{l}\text { relevance and } \\
\text { reliability; } \\
\text { - Ethical dimension: } \\
\text { interact adequately in } \\
\text { cyberspace through } \\
\text { technology, protecting } \\
\text { one's own person and } \\
\text { others. }\end{array}$ & \\
\hline $\begin{array}{lll}\text { S. Carretero, } & \text { R. } \\
\text { Vuorikari \& } & \text { Y. } \\
\text { Punie } & & \end{array}$ & $\begin{array}{l}\text { Digital skills are a } \\
\text { continuum that goes } \\
\text { from the acquisition of } \\
\text { instrumental skills to } \\
\text { the development of } \\
\text { strategic skills, which } \\
\text { allow the person to be } \\
\text { able to distinguish the } \\
\text { stable frame of } \\
\text { reference from those } \\
\text { that are more volatile or } \\
\text { customizable } \\
\text { components. }\end{array}$ & $\begin{array}{l}\text { Five dimensions: } \\
\text { - Information and data } \\
\text { literacy; } \\
\text { - Communication and } \\
\text { collaboration; } \\
\text { - Creation of digital } \\
\text { content; } \\
\text { - Security; } \\
\text { - Solve problems. }\end{array}$ & $\begin{array}{l}\text { The levels of mastery of } \\
\text { the dimension are } 8 \text { and } \\
\text { are grouped into } 4 \\
\text { categories: } \\
\text { - Base: level 1 (with } \\
\text { someone's help), level } 2 \\
\text { (autonomously); } \\
\text { - Intermediate: level } 3 \\
\text { (alone and solving } \\
\text { problems), level } 4 \\
\text { (independent, } \\
\text { according to needs and } \\
\text { solving well-defined } \\
\text { and unsystematic } \\
\text { problems); } \\
\text { - Advanced: level } 5 \\
\text { (promotes support for } \\
\text { others), level } 6 \\
\text { (according to one's own } \\
\text { needs and those of } \\
\text { others in complex } \\
\text { contexts); specialized: } \\
- \text { Highly } \\
\text { level } 7 \text { (highly } \\
\text { specialized), level } 8 \\
\text { (very advanced and } \\
\text { super specialized). }\end{array}$ \\
\hline
\end{tabular}

Sources: (Calvani, Fini, Ranieri, 2009), (Carretero, Vuorikari, Punie, 2017)

The researchers Botteri and Cremonesi (2019) believe that today there are 6 generations: Silent Generation or Traditionals (born 1925-1945), Baby Boomers (born 1946-1964), Generation X 0 Busters (born 1965-1980), Generation Y or Millennials (born 1981-1997), Generation Z or Digital Natives or Founders (born 1997-2010) and Alpha Generation or Screenagers or Net-generation (born after 2010). From the publications of Berkup (2014), Hernaus and Pološki Vokic (2014), Veli ki and Veli ki (2015), Botteri and Cremonesi (2019) have noted that for each generation it was analyzed and typed on the basis of age first and then based on the historical period, personal characteristics, ethics and values, work preferences and current situation. (Table 4). 
Table 4. Differences between generational cohorts

\begin{tabular}{|c|c|c|c|c|c|}
\hline Generation & $\begin{array}{l}\text { Historical } \\
\text { period }\end{array}$ & $\begin{array}{l}\text { Personal } \\
\text { characteristics }\end{array}$ & $\begin{array}{l}\text { Etics and } \\
\text { Values }\end{array}$ & $\begin{array}{l}\text { Work } \\
\text { preferences }\end{array}$ & $\begin{array}{l}\text { Current } \\
\text { situation }\end{array}$ \\
\hline $\begin{array}{l}\text { Silent } \\
\text { Generation } \\
\text { or } \\
\text { Traditionals }\end{array}$ & $\begin{array}{l}\text { Great } \\
\text { Depression } \\
\text { and World } \\
\text { War II }\end{array}$ & $\begin{array}{l}\text {-want to feel } \\
\text { needed } \\
\text {-strive for } \\
\text { financial } \\
\text { security } \\
\text {-"Waste not } \\
\text { want not" } \\
\text { attitude } \\
\text { (Conservatism) } \\
\text {-simplicity, } \\
\text { Patriotic, } \\
\text { Patience, } \\
\text {-high } \\
\text { inter/intra- } \\
\text { personal skills }\end{array}$ & $\begin{array}{l}\text {-traditional } \\
\text { family values } \\
\text {-understands } \\
\text { the nobility of } \\
\text { sacrifice for } \\
\text { the common } \\
\text { good to } \\
\text {-loyal to } \\
\text { employers and } \\
\text { expect the } \\
\text { same in return }\end{array}$ & $\begin{array}{l}\text {-enjoy flexible } \\
\text { arrangements so } \\
\text { they can work on } \\
\text { their own } \\
\text { schedule } \\
\text {-believe } \\
\text { promotions, } \\
\text { raises, and } \\
\text { recognition } \\
\text { should come } \\
\text { from job tenure } \\
\text {-measure work } \\
\text { ethic on } \\
\text { timeliness, } \\
\text { productivity, and } \\
\text { not drawing } \\
\text { attention } \\
\text {-mn typically } \\
\text { worked while } \\
\text { women stayed } \\
\text { home to raise } \\
\text { children }\end{array}$ & $\begin{array}{l}\text {-wealthiest } \\
\text { generation } \\
\text {-majority } \\
\text { are retirees }\end{array}$ \\
\hline $\begin{array}{l}\text { Baby } \\
\text { Boomers }\end{array}$ & $\begin{array}{l}\text { Civil rights } \\
\text { movement, } \\
\text { feminist } \\
\text { movement, } \\
\text { Environment } \\
\text { movement } \\
\text { Cold War } \\
\text { murder of } \\
\text { JFK, Robert } \\
\text { Kennedy and } \\
\text { Martin Luther } \\
\text { King } \\
\text { first man on } \\
\text { the moon } \\
\text { Vietnam War } \\
\text { Protest and } \\
\text { sit-in, } \\
\text { Watergate } \\
\text { Nixon's } \\
\text { resignation }\end{array}$ & $\begin{array}{l}\text {-assertive, } \\
\text { casual, } \\
\text { ambitious, } \\
\text { individualist, } \\
\text { experimentalist } \\
\text {, independent } \\
\text {-optimists, but } \\
\text { distrust of the } \\
\text { government } \\
\text {-promotion of } \\
\text { social causes }\end{array}$ & $\begin{array}{l}\text {-strong } \\
\text { orientation } \\
\text { towards work, } \\
\text { career and } \\
\text { political and } \\
\text { civil } \\
\text { commitment } \\
\text {-respect for } \\
\text { family and } \\
\text { religion }\end{array}$ & $\begin{array}{l}\text {-"Workaholic", } \\
\text { they hold } \\
\text { positions of } \\
\text { prestige, they } \\
\text { have high } \\
\text { incomes and } \\
\text { great capacity to } \\
\text { save } \\
\text {-professionalism } \\
\text { is measured in } \\
\text { hours worked } \\
\text { and little in } \\
\text { productivity } \\
\text {-team worker } \\
\text { with co-workers } \\
\text {-medium-high } \\
\text { education }\end{array}$ & $\begin{array}{l}\text {-generation } \\
\text { with more } \\
\text { people } \\
\text { - } \\
\text { economicall } \\
\text { y launched } \\
\text { group } \\
\text {-"Empty } \\
\text { Nesters" }\end{array}$ \\
\hline \begin{tabular}{l}
\multicolumn{2}{l}{ Generation } \\
$\mathrm{X}$ or \\
Busters
\end{tabular} & $\begin{array}{l}\text { HIV disease } \\
\text { End of Cold } \\
\text { War and } \\
\text { Vietnam's } \\
\text { War }\end{array}$ & $\begin{array}{l}\text {-ambitious, } \\
\text { self-sufficient, } \\
\text { pursuing } \\
\text { personal } \\
\text { development, }\end{array}$ & $\begin{array}{l}\text {-seek stability } \\
\text {-spirit of } \\
\text { adaptation and } \\
\text { responsibility } \\
\text {-distrust in }\end{array}$ & $\begin{array}{l}\text {-informal and } \\
\text { friendly } \\
\text {-freedom and } \\
\text { work flexibility } \\
\text {-place where you }\end{array}$ & $\begin{array}{l}\text {-presence of } \\
\text { single } \\
\text { parents }\end{array}$ \\
\hline
\end{tabular}




\begin{tabular}{|c|c|c|c|c|c|}
\hline & $\begin{array}{l}\text { Watergate } \\
\text { Nixon's } \\
\text { resignation } \\
\text { Computer and } \\
\text { MTV } \\
\text { Fall of the } \\
\text { Berlin wall } \\
\text { Reaganism }\end{array}$ & $\begin{array}{l}\text { organized and } \\
\text { multi-tasking, } \\
\text { open to } \\
\text { dialogue, } \\
\text { tolerant towards } \\
\text { differences, } \\
\text { flexibles but } \\
\text { realistic, and } \\
\text { rejecting the } \\
\text { rules } \\
\text {-defined as } \\
\text { "nothingers", } \\
\text { but they need to } \\
\text { control their } \\
\text { lives }\end{array}$ & $\begin{array}{l}\text { institutions, } \\
\text { it's believed in } \\
\text { people and not } \\
\text { in the family } \\
\text {-children must } \\
\text { be self- } \\
\text { sufficient }\end{array}$ & $\begin{array}{l}\text { can always learn } \\
\text {-more quality, } \\
\text { less quantity } \\
\text {-communication } \\
\text { regardless of } \\
\text { position or title }\end{array}$ & \\
\hline $\begin{array}{l}\text { Generation } \\
\text { Y } \quad \text { or } \\
\text { Millennials }\end{array}$ & $\begin{array}{l}\text { Technologica } \\
1 \text { development } \\
\text { Oklahoma } \\
\text { bombing } \\
\text { OJ Simpson } \\
\text { case } \\
\text { Death of } \\
\text { Princess } \\
\text { Diana } \\
\text { Y2K } \\
\text { Terrorism } \\
\text { suine flu }\end{array}$ & $\begin{array}{l}\text {-the "mummy's } \\
\text { boys" leave } \\
\text { home late in life } \\
\text {-concentrated } \\
\text { on the present, } \\
\text { hyper- } \\
\text { connected, } \\
\text { receptive and } \\
\text { multitasking } \\
\text { and possessing } \\
\text { profound } \\
\text { technological } \\
\text { knowledge } \\
\text {-have a visual } \\
\text { approach rather } \\
\text { than a textual } \\
\text { one } \\
\text {-accept } \\
\text { diversity and } \\
\text { work together } \\
\text {-achieving } \\
\text { goals in a short } \\
\text { time and with } \\
\text { people helping } \\
\text { them } \\
\text {-ambitious, } \\
\text { optimistic, } \\
\text { impatient, } \\
\text { entrepreneurial, } \\
\text { individualistic, } \\
\text { informali } \\
\text {-short attention } \\
\text { and immediate } \\
\text { gratification } \\
\text {-be unique }\end{array}$ & $\begin{array}{l}\text {-attentive to } \\
\text { the image } \\
\text {-they buy not } \\
\text { to have, but to } \\
\text { be } \\
\text {-everyone } \\
\text { wins! }\end{array}$ & $\begin{array}{l}\text {-accustomed to } \\
\text { insecurity } \\
\text {-the job is not } \\
\text { aimed at salary, } \\
\text { but they prefer to } \\
\text { be remembered } \\
\text { and make a } \\
\text { difference } \\
\text {-curious and } \\
\text { open to new } \\
\text { things in an } \\
\text {-work is } \\
\text { opportunity to } \\
\text { learn } \\
\text {-work to live, } \\
\text { rather than live } \\
\text { to work }\end{array}$ & - \\
\hline
\end{tabular}




\begin{tabular}{|c|c|c|c|c|c|}
\hline $\begin{array}{l}\text { Generation } \\
Z \text { or Digital } \\
\text { Natives o } \\
\text { Founders }\end{array}$ & $\begin{array}{l}\text { 11 September } \\
2011 \\
\text { Great } \\
\text { recession } \\
\text { Terrorism } \\
\text { suine flu } \\
\text { hurricane } \\
\text { Katrina } \\
\text { iPod and } \\
\text { Facebook } \\
\text { World Wide } \\
\text { Web }\end{array}$ & $\begin{array}{l}\text {-innovative } \\
\text { choice } \\
\text {-highly } \\
\text { connected to } \\
\text { communicate } \\
\text {-immediate } \\
\text { information } \\
\text { (status on FB } \\
\text { and/or Twitter) } \\
\text { and little } \\
\text { concern for } \\
\text { privacy except } \\
\text { for money } \\
\text {-immediate and } \\
\text { quick gratification } \\
\text {-independent } \\
\text {-they suffer } \\
\text { from the fear of } \\
\text { being excluded }\end{array}$ & $\begin{array}{l}\text {-value to the } \\
\text { family and to } \\
\text { the elderly, but } \\
\text { they challenge } \\
\text { the traditional } \\
\text { roles } \\
\text {-unstable } \\
\text { couple } \\
\text { relations }\end{array}$ & $\begin{array}{l}\text {-education and } \\
\text { training through } \\
\text { the use of social } \\
\text { media } \\
\text {-no team worker, } \\
\text { but they will be } \\
\text { very self-critical, } \\
\text { they will process } \\
\text { information at } \\
\text { light speed } \\
\text { thanks to } \\
\text { cunning } \\
\text {-turning passion } \\
\text { into work }\end{array}$ & $\begin{array}{l}\text {-multiracial } \\
\text {-they will } \\
\text { have to } \\
\text { resolve the } \\
\text { environmen } \\
\text { tal, social } \\
\text { and } \\
\text { economic } \\
\text { deterioratio } \\
\text { n }\end{array}$ \\
\hline $\begin{array}{l}\text { Generation } \\
\text { Alpha o } \\
\text { Screenagers } \\
\text { o Net- } \\
\text { generation }\end{array}$ & Today & $\begin{array}{l}\text {-they pass the } \\
\text { evolutionary } \\
\text { stages } \\
\text {-the most } \\
\text { experienced in } \\
\text { technology } \\
\text {-they know } \\
\text { perfectly how } \\
\text { to use } \\
\text { technology } \\
\text {-possible } \\
\text { dependence on } \\
\text { the screens } \\
\text {-time spent on } \\
\text { devices is } \\
\text { greater than } \\
\text { social time } \\
\text {-virtual } \\
\text { friendships } \\
\text {-feeling of } \\
\text { loneliness, } \\
\text { despite the } \\
\text { hyper- } \\
\text { connection }\end{array}$ & - & $\begin{array}{l}\text {-longer students } \\
\text { and independent } \\
\text { adults later }\end{array}$ & $\begin{array}{l}\text {-look after } \\
\text { their parents } \\
\text { for a longer } \\
\text { period of } \\
\text { time } \\
\text {-particularly } \\
\text { demanding } \\
\text { consumers } \\
\text {-particularly } \\
\text { unfaithful } \\
\text { customers }\end{array}$ \\
\hline
\end{tabular}




\section{DIGITAL SKILLS AND PROFILE OF EACH GENERATION: A REVIEW}

\section{DISCUSSION}

Today the digital skills are a necessary skill for everyday life since they are applied in every social context. The diversity of social contexts makes it emerge a multiplicity of professionals working in the technological field. This multiplicity of figures increasingly requires a common and shared theoretical dimension as each professional tends to give meanings to this mediator. From the analysis of all the publications it is believed that the two most complete theories are those of the scholars Calvani, Fini, Ranieri (2009) and those of Carretero, Vuorikari, Punie (2017). For both research groups the definition of digital skills is very dynamic and multiple since it is the union of many different skills. These skills can be divided into basic or procedural skills and more complex skills. Basic skills mean: exploring, searching, exchanging information, data, ... Instead, the scholars for more complex skills tend to mean: the ability to select, interpret, evaluate information, technological devices, create technological content,... Calvani, Fini and Ranieri (2009) tend to divide these skills into 4 different dimensions: the technological dimension, the basic notions in the choice of technologies in a flexible way; cognitive dimension, access, evaluation and critical selection of data; ethical dimension, the ethical and correct use of technologies; the integrated dimension, the creation of knowledge thanks to the use of technology. The second contribution concerning these digital skills is that of DigComp 2.0 / 2.1 prepared by Carretero, Vuorikari, Punie (2017). Their model tends synthetically to bring out 5 different dimensions of competences: literacy on information and data; communication and collaboration; content creation; safety; problem solving. Both contributions have included the ways in which these skills can be evaluated and a scale of mastery of competence's dimensions. It is in fact believed that knowing how to identify the current development area of the person and his / her already possessed competences allows us to design inclusive paths and products that promote the potential development of the human being in these technological competences favoring his quality of life and its centrality (Vygotskij, 2008). Being close to Vygotsky's statement, it was decided to focus on the different generations present and socially active. Initially the most current macro-classification in the literature was analyzed. Later it was an intergenerational comparison based on elements shared by different authors. From the analysis of the various studies, summarized in Table 4, these differences are clear: the conservative, patriotic Silent Generation, strongly anchored to family values and centered on job satisfaction, on sacrifice for the common good, on the centrality of man (the man works, while the woman stays at home to look after the children), then moves on to the Baby Boomers who despite being born a few years later tend to be much more ambitious, individualistic and independent of their predecessors. They are "Workaholics", professionalism is measured by the amount of work hours and not productivity. This last attitude is very different from Generation X or Busters, which tend instead to prefer quality over quantity of work; they also appear to be more unstable both in work and in the family as they pursue personal development, rejecting the rules and trying to gain control of their lives. The perceived instability experienced by this generation turns into insecurity for Generation $Y$ or Millennials, who prefer to be centered on the present, are more curious and open to new things, see work as fun and want to stand out from others. They are the first generation that tends not to deepen their choices and to request immediate gratification. In the wake of this generation follows the Generation Z or Digital Natives or Founders, who want to turn their passion into a job, they too seek immediate gratification and are highly connected despite suffering the fear of being excluded. They are independent, self-critical and suffer from social instability in couple relationships. Finally, we come to the analysis of the studies carried out with Alpha Generation or Screenagers or Net-generation, which pass all the evolutionary stages, spend more time on devices than social and / or family time. Adult independence will be considerably delayed due to the many years they will be studying. They have a greater sense of solitude 
despite the hyper-internet connection compared to the previous generation. Some scholars, regarding this generation, speak of a possible dependence of the screens.

\section{CONCLUSIONS}

This preliminary research has fulfilled the set objectives, since it is believed that this article allows different professionals to have a broader theoretical vision. The two theories for digital skills allow to have an answer to the theoretical-methodological emergency in this field of investigation where the multidisciplinarity of the professional figures involved is very present. In fact, there are both professionals in the humanities and technical-scientific areas. In the wake of this, having a macro and a micro-classification of the population in the light of generational profiles helps the various professionals in the design of training courses or products that start from the potential of each age to improve their quality of life. Knowing the potential of people favors the success of every design, since the centrality of the person is the fundamental node. This highlights the analyzed studies given that the differences of each generation influence and considerably modify the methods of approach and interaction in social contexts. Even more so in the technological field where the purposes of interaction are multiple and different.

It is believed that this research represents a starting point since we have already been working on a research centered more on the perception that each generation has regarding technological development. Having a clear understanding of the theoretical dimension regarding digital skills and generational profiles, allows us in in-depth research to observe whether this perception is influenced by the digital skills possessed and the respective generational profile.

\section{REFERENCES}

Behrstock-Sherratee, E., \& Coggshall, J. (2010). Realizing the promise of Generation Y. Educational Leadership, 67(8), 28-34.

Berkup, S. B. (2014). Working with generations $X$ and $Y$ in generation $Z$ period: Management of different generations in business life. Mediterranean Journal of Social Sciences, 5(19), 218-229.

Botteri, T., \& Cremonesi, G. (2019). Millennials e oltre!: Nuove generazioni e paradigmi manageriali. Milano: Franco Angeli.

Calvani A. (2006). Tecnologie, scuola, processi cognitivi. Per una ecologia dell'apprendere. Milano: Franco Angeli.

Calvani, A., Fini, A., \& Ranieri M. (2009). Valutare la competenza digitale. Modelli teorici e strumenti applicative. Italian Journal of Educational Technology, 17(3), 39-46.

Calvani, A., Fini, A., \& Ranieri, M. (2010). La competenza digitale nella scuola. Trento: Erickson.

Carretero, S., Vuorikari, R., \& Punie, Y. (2017). DigComp 2.1: The Digital Competence Framework for Citizens with eight proficiency levels and examples of use. Publications Office of the European Union. Retrieved from http://publications.jrc.ec.europa.eu/repository/bitstream/JRC106281/webdigcomp2.1pdf_(online).pdf

Gallina, P. (2019). La mente liquida. Come le macchine condizionano, modificano o potenziano il cervello. Bari: DEDALO.

Hernaus, T., \& Pološki Vokic, N. (2014). Work design for different generational cohorts: Determining common and idiosyncratic job characteristics. Journal of Organizational Change Management, 27(4), 615-641.

Iannone, R., Gurashi, R., Iannuzzi, I., \& Sessa, M. (2018). The smart home in the mind and in the practice of digital natives. The case of "Sapienza" University". Storiadelmondo, 86 http://www.storiadelmondo.com/86/sapienza.home.pdf 
ISTAT. (n.d). Cittadini, imprese e ICT. Retrieved 6 Febrary, 2019, from https://www.istat.it/it/files//2019/01/Report-ICT-cittadini-e-imprese_2018_PC.pdf

Kiser, A., \& Washington, R. (2015). The Information Gap amongst the Generations and the Implications for Organizations. International Journal of Digital Literacy and Digital Competence, 6(2), 36-63.

Kubiato, M. (2013). The comparison of different age groups on the attitudes and use of ICT. Educational Sciences: Theory and Practic, 13(2), 1263-1272.

MIUR. (n.d.). Piano Nazionale Scuola Digitale. Retrieved 11 March, 2019, from http://www.istruzione.it/scuola_digitale/allegati/Materiali/pnsd-layout-30.10-WEB.pdf

Oblinger, D., \& Oblinger, J. (2005). It is age or IT: First steps towards understanding the net generation. In D. Oblinger and J. Oblinger (Eds.), Educating the Net Generation (pp. 1.1-1.5) Washington, DC: Educause.

Risi, S. (2007). Vecchie generazioni e nuovi media. Milan: University of Bologna.

Rogers, M. (2010). Technology and baby boomers". World Future Review, 2(3), 54-59.

Vygotskij, L. S. (2008). Pensiero e linguaggio. Ricerche psicologiche. Italy: Laterza.

Veli ki, D., \& Veli ki, V. (2015). Characteristics and particularities of educating the net-generation. In The 2015 WEI International Academic Conference Proceesdings, Prague: The West East Institute.

@SCRITTURE DI RETE. (2017). Evoluzione Tecnologica: Generazioni a confronto. Retrieved from https://scritturedirete.wordpress.com $/ 2017 / 12 / 30 / \% \mathrm{F0} \% 9 \mathrm{~F} \% 85 \% 94$ voluzione\%F0\%9F\%85\%A3ecnologica-generazioni-a-confronto/ 